\title{
Agranulosit Bibit Sapi Bali pada Berbagai Umur di Nusa Penida
}

\author{
(AGRANULOSIT OF BALI CATTLE ON VARIOUS AGE IN NUSA PENIDA)
}

\author{
Franky Lunggi Hali Remi Andung ${ }^{1}$, Ni Ketut Suwiti², Anak Agung Sagung Kendran ${ }^{3}$ \\ ${ }^{1}$ Praktisi Dokter Hewan di Kupang, \\ ${ }^{2}$ Laboratorium Histologi Veteriner Universitas Udayana, \\ ${ }^{3}$ Laboratorium Patologi Klinik Veteriner Universitas Udayana, \\ Jln. PB. Sudirman Denpasar-Bali \\ Email: andunganki@gmail.com
}

\begin{abstract}
ABSTRAK
Penelitian bertujuan untuk mengetahui perbandingan persentase agranulosit terhadap umur bibit sapi bali. Penelitian ini menggunakan sapi bali betina yang dipelihara di wilayah Nusa Penida, dengan tiga rentangan umur yang berbeda yakni pedet, dara, dan dewasa. Pengambilan sampel darah dilakukan melalui vena jugularis menggunakan venoject dan langsung dilakukan pembuatan apusan darah di tempat. Preparat kemudian diamati dan dihitung di bawah mikroskop dengan pembesaran 1000 kali menggunakan metode cross sectional, jumlah limfosit dan monosit diamati serta dihitung per 100 sel leukosit. Data yang didapatkan selanjutnya dianalisis menggunakan uji sidik ragam one way anova. Hasil yang didapatkan menunjukkan adanya perbedaan persentase limfosit yang sangat nyata pada tingkatan umur pedet, dara dan dewasa. Sedangkan monosit tidak terdapat perbedaan yang nyata. Berdasarkan hasil penelitian diperoleh bahwa persentase limfosit pada umur dewasa lebih tinggi dibandingkan dengan umur pedet dan dara tetapi masih berada dalam rentangan nilai normal limfosit. Sedangkan persentase monosit memiliki nilai yang sama pada umur dewasa, dara dan pedet.
\end{abstract}

Kata kunci: Sapi bali; leukosit; limfosit; monosit.

\section{ABSTRACT}

The study aims to determine the percentage ratio of agranulocytes at several ages of of Bali cattle calve. This study used female Bali cattle which reared in the area of Nusa Penida, with three different age ranges namely the calves, the virgins, and the adults. The blood sampling was performed through the jugular vein using venoject and it was instantly made a blood smear on the research sites. The preparation was observed and calculated under a microscope with a magnification of 1000 times using cross sectional method, the number of lymphocytes and monocytes were observed and calculated per 100 leukocytes. The data obtained were then analyzed by using analysis of variance test one-way Anova. The results indicated a difference in the percentage of lymphocytes was very significant on the calves the virgins, and the adults's age level. While there were no significant differences on monocytes. The results showed that the percentage of lymphocytes in adults age is higher than the age of the calves and the virgins. While the percentage of monocytes has the same value at age.

Keywords: Bali cattle; leukocytes; lymphocytes; monocytes.

\section{PENDAHULUAN}

Kecamatan Nusa penida merupakan salah satu wilayah yang masuk dalam Kabupaten Klungkung Provinsi Bali, dengan kondisi topografinya tergolong landai sampai berbukit. Desa - desa pesisir di sepanjang pantai bagian utara berupa lahan datar dengan kemiringan 0-3\% dari ketinggian lahan 0-268 mdpl. Pulau dengan luas $\pm 414 \mathrm{~km}$ ini memiliki potensi peternakan sehingga pada tahun 2013 dijadikan pusat pemurnian dan pembibitan sapi bali oleh pemerintah berdasarkan PP nomor 48 tahun 2011.

Sapi bali (Bibos sondaicus) merupakan hasil domestikasi dari banteng liar (Bibos banteng) dan memiliki berbagai keunggulan (Handiwirawan dan Subandriyo, 2004). Sapi bali ini merupakan sumber daya genetik asli Indonesia yang perlu dijaga dan dipelihara kelestariannya sehingga dapat memberikan manfaat dalam peningkatan kesejahteraan dan kemakmuran rakyat Indonesia. Salah satu 
persyaratan dalam menentukan mutu bibit sapi bali yang baik adalah bebas dari segala bentuk cacat fisik dan bebas dari penyakit.

Salah satu penyakit yang dapat menyerang sapi bali adalah penyakit jembrana (Jembrana Disease). Menurut Suwiti (2009) penyakit ini merupakan salah satu penyakit strategis karena penyakit ini hanya menyerang sapi bali dan ditemukan hanya di Indonesia. Sampai saat ini sapi bali di Nusa Penida dinyatakan bebas terhadap penyakit jembrana. Penyakit jembrana atau yang dikenal dengan JD (Jembrana Disease) merupakan suatu penyakit yang menyerang pada sapi Bali disebabkan oleh virus penyakit jembrana $($ Jembrana Disease Virus $=$ JDV) termasuk dalam kelompok retrovirus. Gejala umum yang ditunjukan oleh ternak terserang penyakit jembrana adalah demam tinggi, lymphadenopathy, lymphopenia, keringat darah dan mukus yang berlebihan pada mulut dan hidung (Indriawati at al., 2013). Salah satu indikator yang dapat digunakan untuk mengetahui adanya suatu infeksi pada hewan ternak adalah dilihat dari jumlah limfosit dan monosit.

Limfosit dan monosit merupakan bagian dari sistem pertahan tubuh. Kerentanan ternak terhadap penyakit dalam hal ini sapi bali sangat dipengaruhi oleh sistem pertahanan yang dimiliki. Sistem pertahanan tubuh terdiri atas komponen sel darah putih (leukosit). Leukosit dibedakan atas sel yang bergranula (granulosit) dan sel yang tidak bergranula (agranulosit). Agranulosit merupakan bagian dari sel darah putih yang terbentuk dari hasil proses diferensiasi sel-sel progenitor pada sumsum tulang menjadi limfosit $\mathrm{T}$, limfosit $\mathrm{B}$ dan monosit (Corwin, 2009). sel limfosit memiliki kemampuan untuk menghasilkan antibodi terhadap antigen yang akhirnya membuat ketahanan tubuh akan lebih baik (Puspawanti dan Rungkat, 2012). Menurut Lokapirnasari (2014) monosit berperan sebagai prekursor untuk makrofag, dan sel ini akan mencerna dan mengenali antigen.

Faktor lingkungan faktor internal juga berpengaruh terhadap ketahanan tubuh sapi, salah satunya adalah faktor umur hewan. Menurut Nurhayati (2015) umur merupakan salah satu faktor yang menentukan hewan untuk mudah tidaknya terinfeksi mastitis pada sapi perah. Sedangkan tempat predileksi Cysticercus bovis pada sapi bali selain ditentukan oleh aktivitas otot dan berdasarkan area geografis juga ditentukan oleh faktor umur (Purna et al., 2014). Dengan demikian maka perlu adanya penelitian mengenai perbandingan agranulosit pada bibit sapi bali yang dipelihara di Nusa Penida.

\section{METODE PENELITIAN}

\section{Sampel Penelitian}

Sampel yang digunakan adalah darah sapi bali betina sehat yang dipelihara di Nusa Penida. Sampel seluruhnya berjumlah 60 ekor yang diambil berdasarkan umur yakni pedet dara dan dewasa dengan jumlah sampel masing-masing 20 ekor. Bahanbahan yang digunakan adalah methanol, alkohol $70 \%$, giemza $10 \%$, dan minyak emersi. Alat yang digunakan adalah objek glass, pipet, gelas ukur, venoject, mikroskop, kapas dan stening jar.

\section{Metode Penelitian}

Jumlah sampel minimal ditentukan berdasarkan rumus:

$$
n=\frac{N\left(z^{2}-\frac{\alpha}{2}\right) S D^{2}}{(N-1) d^{2}+\left(z^{2}-\frac{\alpha}{2}\right) S D^{2}}
$$

Sumber: Zainuddin (1999),

Ket: $\mathrm{n}=$ sampel minimum, $\mathrm{N}=$ besar populasi, $Z^{2}-\frac{\alpha}{2}=$ nilai distribusi normal baku (table Z) pada a tertentu, SD = standar deviasi dan $\mathrm{d}=$ penyimpangan yang ditolerir. Bila diketahui nilai $\mathrm{SD}=1,01$ (saragih, 2014), $Z^{2}-\frac{\alpha}{2}=1,96, \mathrm{~N}=18.949$ (BPS klungkung, 2013 dalam saragih, 2014), $d=0,3$ maka jumlah sampel minimal yang diperlukan:

$$
\mathrm{n}=\frac{18.949 \times 1,96 \times 1,01^{2}}{(18.949-1) 0,3^{2}+1,96 \times 1.01^{2}}=21 \text {. }
$$

Dengan demikian jumlah sampel minimal yang dibutuhkan dalam penelitian adalah 21 ekor.

Penelitian menggunakan rancangan acak lengkap (RAL) dengan memakai 
metode rambang atau random cluster sampling dalam pengumpulan sampel. Tahapan pengumpulan data diawali dengan pembagian kelas pada sapi berdasarkan umurnya yakni pedet, dara dan dewasa untuk pengambilan sampel. Sampel didapatkan melalui pengambilan spesimen darah sapi bali di melalui vena jugularis menggunakan venoject dan langsung dilakukan pembuatan apusan darah di tempat. Pembuatan apusan darah dilakukan dengan menggunakan objek glass dan difiksasi menggunakan methanol selama lima menit terlebih dahulu, selanjutnya dilakukan pewarnaan Giemsa selama \pm 20 menit lalu dibersihkan dibawah air mengalir. Selanjutnya data didapatkan melalui pemeriksaan preparat apusan yakni diamati dan dihitung di bawah mikroskop dengan pembesaran 1000 kali menggunakan metode cross sectional (Weiss dan Wardrop, 2010 dalam utama et al, 2013). Jumlah limfosit dan monosit yang diamati akan dihitung per 100 sel leukosit.

\section{Analisis Data}

Data agranulosit yang didapatkan dari pemeriksaan dan penghitungan dibawah mikroskop dianalisis pada software spss statistic 17 dengan menggunakan uji one way anova (analysis of variance) dan bila terdapat perbedaan rataan maka dilanjutkan dengan uji jarak berganda Duncan (Duncan's Multiple Range Test).

\section{HASIL DAN PEMBAHASAN Hasil}

Leukosit merupakan bagian dari darah yang berfungsi sebagai sistem pertahanan tubuh. Dalam hal ini sel leukosit terbagi atas dua yakni golongan yang tidak bergranula yang terdiri dari limfosit dan monosit, dan golongan yang bergranula yaitu neutrofil, eusinofil dan basofil. Adanya perbedaan sistem imun/ respon imun sapi bali mengingat sel limfosit merupakan sel yang dapat menghasilkan antibodi terhadap antigen dalam tubuh yang digunakan sebagai indikator respons imun dan dapat memacu kerja sistem imun dalam tugasnya mempertahanan kesehatan tubuh hewan. Limfosit dibedakan atas sel limfosit $B$ berperan dalam imunitas humoral sedangkan sel limfosit $\mathrm{T}$ berperan dalam imunitas seluler.

Sedangkan monosit merupakan leukosit yang berperan juga didalam pertahanan tubuh. Jumlahnya pada sapi bali apabila dibandingkan dengan monosit sapi lainnya didaerah lain lebih tinggi. Keadaan ini dapat menyebabkan sistem imun sapi bali lebih bagus karena monosit ini memiliki peran sebagai prekursor untuk makrofag, dan sel ini akan mencerna dan membaca antigen.

Tabel 1. Persentase rataan limfosit dan monosit

\begin{tabular}{ccc}
\hline \multirow{2}{*}{ Umur } & \multicolumn{2}{c}{ Leukosit Agranulosit } \\
\cline { 2 - 3 } & Limfosit & Monosit \\
\hline Pedet & $65.15 \pm 4.06^{\mathrm{a}}$ & $4.50 \pm 2.23^{\mathrm{a}}$ \\
Dara & $69.40 \pm 2.96^{\mathrm{b}}$ & $4.50 \pm 2.32^{\mathrm{a}}$ \\
Dewasa & $72.45 \pm 2.16^{\mathrm{c}}$ & $5.25 \pm 1.71^{\mathrm{a}}$ \\
\hline Total & $69.00 \pm 4.334$ & $4.75 \pm 2.104$ \\
\hline
\end{tabular}

Keterangan: Nilai dengan huruf yang sama menunjukkan tidak berbeda nyata $(\mathrm{p}>0.05)$ sedangkan nilai dengan huruf yang berbeda menunjukkan berbeda nyata $(\mathrm{p}<0.05)$.

Hasil penelitian yang didapatkan yakni limfosit pada sapi bali yang dipelihara di Nusa Penida memiliki nilai rataan yang berbeda pada tiap kelompok umur yakni pedet sebesar $65,15 \% \pm 4.06$, sapi dara sebesar $69,40 \% \pm 2.96$, dan sapi dewasa sebesar $72,45 \% \pm 2.16$. Untuk monosit nilai rataan yang didapatkan pada umur pedet dan sapi dara memiliki nilai yang sama sebesar $4,50 \%$ dengan standar deviasi masing - masing sebesar 2.32 pedet dan 2.23 pada dara lalu mengalami peningkatan pada umur dewasa sebesar $5,25 \% \pm 1.71$. Persentase yang didapatkan tersebut masih berada didalam batas yang normal. Nilai limfosit yang diperoleh $69 \%$ dan nilai monositnya adalah $4,75 \%$ dan apabila dibandingkan dengan penelitian Pawitri el al. (2014) yakni untuk kisaran persentase nilai normal sapi adalah limfosit 45-75\% dan monosit 2-7\%. 


\section{Pembahasan}

Hasil uji oneway anova menunjukkan bahwa persentase limfosit pada bibit sapi bali dewasa lebih tinggi dibandingkan dengan pedet dan dara yang dikategorikan sebagai umur muda dengan peningkatan persentase yang sangat signifikan $(\mathrm{p}<0,01)$. Hasil penelitian ini menunjukkan bahwa terdapat peningkatan persentase limfosit seiring bertambahnya umur pada sapi bali.
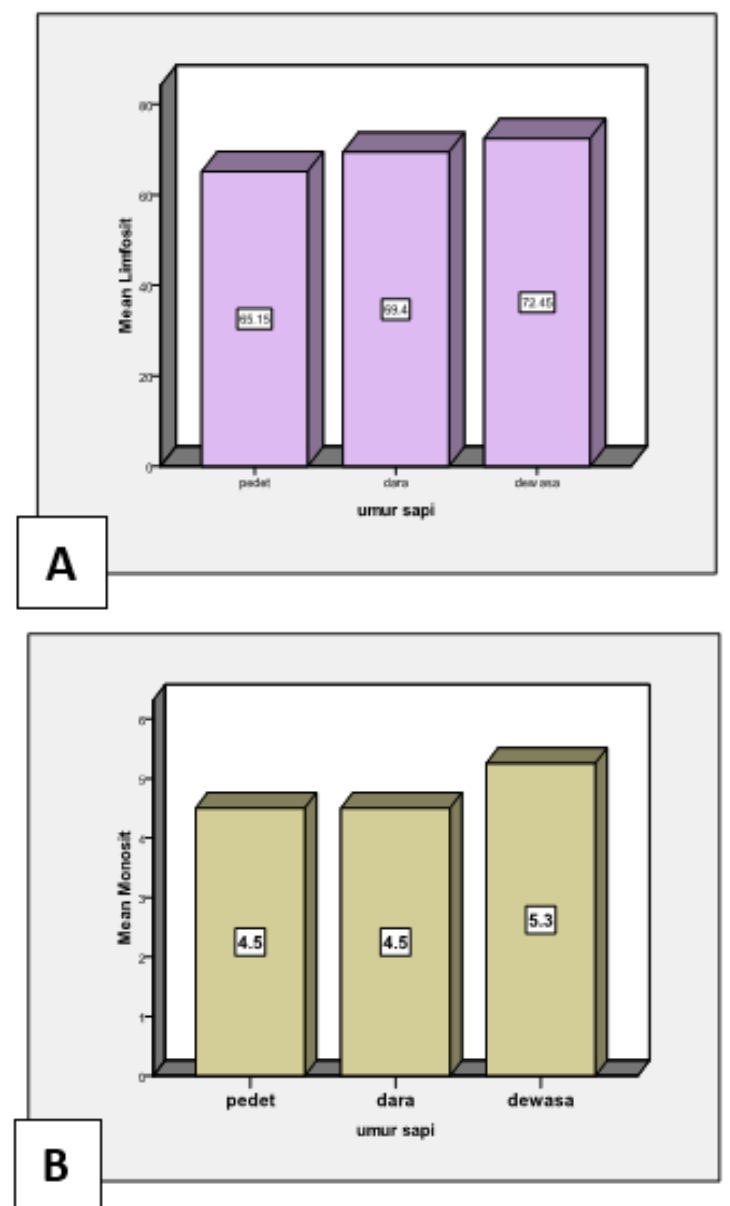

Gambar 1. Grafik persentase Limfosit (A) dan monosit (B)

Peningkatan sel limfosit atau limfositosis dari nilai normalnya dapat diakibatkan oleh adanya infeksi virus, infeksi kronis, leukemia limfositik, insufiensi korteks adrenal dan adanya vaksinasi. Sedikit atau banyaknya kenaikan sel limfosit dari nilai normalnya tersebut ditentukan oleh beberapa faktor, misalnya pada infeksi virus tingginya kenaikan limfosit bergantung pada tingkat keparahan penyakit yang disebabkan virus tersebut. Pada peningkatan sel leukosit karena vaksinasi terjadi karena adanya proses proliferasi leukosit untuk membentuk zat kebal pada tubuh (Siswanto et al., 2016), tingginya peningkatan ini bergantung dari jenis vaksin yang digunakan. Penurunan sel limfosit atau limfositopenia juga bisa diakibatkan karena faktor stress, trauma, dan suhu lingkungan. Pada kasus penyakit jembrana yang menyerang sapi bali sel limfosit merupakan sel yang paling banyak terinfeksi jembrana disease virus (JDV) (Berata, 2010).

Penurunan monosit atau monositopenia jarang terjadi dan dianggap tidak mengandung arti yang penting (Dharmawan, 2002; Stockham dan Scott, 2008 dalam Putra et al., 2016). Menurut Kececi dan Col (2011) bahwa seiring bertambahnya umur pada burung pegar maka persentase leukosit akan semakin meningkat. Egbe-Nwiyi et al. (2000) juga menyatakan bahwa umur dan jenis kelamin berpengaruh terhadap jumlah limfosit dan monosit pada domba dan kambing di Nigeria. Secara umum hal ini berkaitan kerentanan terhadap penyakit yakni hewan muda memiliki kerentanan terhadap infeksi penyakit jika dibandingkan dengan hewan dewasa. Adanya perbedaan sistem imun/ respon imun sapi bali mengingat sel limfosit merupakan sel yang dapat menghasilkan antibodi terhadap antigen dalam tubuh yang digunakan sebagai indikator respons imun dan dapat memacu kerja sistem imun dalam tugasnya mempertahanan kesehatan tubuh hewan.

\section{SIMPULAN DAN SARAN}

\section{Simpulan}

Persentase limfosit pada umur dewasa lebih tinggi dibandingkan dengan umur pedet dan dara. Sedangkan persentase monosit memiliki nilai yang sama pada umur dewasa, dara dan pedet.

\section{Saran}

Perlu adanya penelitian lebih lanjut mengenai leukosit agranulosit untuk mengetahui faktor lain yang mempengaruhi persentase agranulosit pada bibit sapi bali yang dipelihara di wilayah Nusa Penida 


\section{UCAPAN TERIMAKASIH}

Terima kasih kepada Puskeswan Nusa Penida dan BBvet denpasar atas bimbingan serta bantuannya dalam pengumpulan sampel di Nusa Penida.

\section{DAFTAR PUSTAKA}

Berata IK. 2010. Penyakit Jembrana Sapi Bali Berdasarkan Karakteristik Sel terinfeksi Pada Jaringan Limfoid Dan Darah Tepi. Bul. Vet. Udayana. 2(1): 35-44.

Corwin EJ. 2009. Buku Saku Patofisiologi. Edisi 3. Subekthi, N.B., E.K. Yudha, E. Wahyunigsih, D Yulianti, P.E Karyoni. Penerbit Kedokteran EGC. Jakarta.

Egbe-nwiyi TN, Nwaosu SC, Salami HA. 2000. Haematological values of appararently healthy sheep and goats as influenced by age and sex. Af. $J$. Biomed. Res. 3: 109-115.

Handiwirawan E, Subandriyo. 2004.Potensi dan Keragaman Sumberdaya Genetik Sapi Bali. Wartazoa. 14(3).

Indriawati, Margawati ET, Ridwan M. 2013. Identifikasi Virus Penyakit Jembrana Pada Sapi Bali Menggunakan Penanda Molekuler Gen Env SU. Berita Biologi. 12(2): 211-216.

Keçeci T, Çöl R. 2011. Haematological and biochemical values of the blood of pheasants (Phasianus colchicus) of different ages. Turk. J. Vet. Anim. Sci. 35(3): 149-156.

Lokapirnasari WP, Yulianto AB. 2014. Gambaran Sel Eosinofil, Monosit, dan Basofil Setelah Pemberian Spirulina Pada Ayam Yang Diinfeksi Virus Flu Burung. J. Vet. 15(4): 499-505.

Nurhayati IS, Martindah E. 2015. Pengendalian Mastitis Subklinis melalui Pemberian Antibiotik Saat
Periode Kering pada Sapi Perah. Wartazoa. 25(2): 065-074.

Pawitri NLPS, Dwinata IM, Dharmawan NS.2014. Diferensial Leukosit Sapi Bali yang Terinfeksi Cysticercus Bovis Secara Eksperimental. Indon. Med. Vet. 3(3): 213-222.

Purna RA, Dwinata IM, Dharmawan NS. 2014. Distribusi dan Jumlah Cysticercus bovis pada Sapi Bali yang Diinfeksi Telur Taenia saginata Empat Bulan Pasca Infeksi. Indon. Med. Vet. 3(5): 359-366.

Putra IPC, Suwiti NK, Ardana, IBK. 2016. Suplementasi Mineral Pada Pakan Sapi Bali Terhadap Diferensial Leukosit Di Empat Tipe Lahan. Bul. Vet. Udayana. 8(1): 8-16.

Puspawati GAKD, Rungkat FZ. 2012. Peningkatan Proliferasi Limfosit Limpa pada Tikus yang Diberi Makan Sorgum. J. Vet. 13(1): 26-33.

Saragih CI. 2014. Profil Hormon pertumbuhan Sapi Bali di Kecamatan Nusa Penida Kabupaten Klungkung Provinsi Bali. Thesis. Universitas Udayana. Denpasar.

Siswanto, Sulabda IN, Soma IG. 2016. Titer Antibodi dan Hitung Jenis Leukosit Ayam Potong Jantan Pasca Vaksinasi Virus Newcastle Disease. Indon. Med. Vet. 5(1): 89-95.

Suwiti NK. 2009. Fenomena Jembrana Disease Dan Bovine Immunodeficiency Virus Pada Sapi Bali. Bul. Vet. Udayana. 1(1): 21-25.

Utama IH, Kendran AAS, Widyastuti SK, Virgania P, Sene SM, Kusuma WD, Arisandi BY. 2013. Hitung Diferensial dan Kelainan-Kelainan Sel Darah Sapi Bali. J. Vet. 14 (4): 462-46.

Zainuddin M. 1999. Metodologi Penelitian. Unair Press. Surabaya. 